\title{
The Spirit of Islam in the Development of Good Governance and Anti-Corruption Concepts
}

\author{
Ulul Albab \\ \{dr.ululalbab@gmail.com\} \\ Teaching Staff at Faculty of Administrative Science, Dr. Soetomo University, Indonesia
}

\begin{abstract}
The research was focused on two problems. First, what were the Islamic teachings promoting corruption-free governance? Second, what was the governance model making use of the basic principles of Islamic teachings (as reasoning background) as preventive efforts to eradicate corruption? The research was conducted in a qualitative method by applying library research. The primary data were collected from the Quran verses and the Hadith concerning lessons for governance and anti-corruption. The interpretive analysis was a thematic construal of the Quran and the Hadith into a viewpoint for either a concept or a model for the nation's problem solving. There were two results of the research. First, through a study on the Quran and the Hadith, there were at least five principles obtained for good and corruption-free governance: at-taqwa (God-consciousness), al-adl (just), al-amanah (trust), al-mas'uliyah (responsibility), and al-imarah (governance). Second, a new governance model for good and anti-corruption governance. The model was subsequently developed into a list of recommended operational activities for realizing good and anti-corruption governance.
\end{abstract}

Keywords: Islamic principles, good governance, anti-corruption

\section{Introduction}

The studies of anti-corruption, especially the ones paying special attention to the causal factors of the occurrence of corruption, states that the causal factors of corruption cover: (1) Poor salary; (2) Ample opportunities for corruption; (3) Low risk of detection and punishment (see: Corpuz, 1957; Suwanagul, 1962; Day, 1966; Mackie, 1970; Knapp; 1972; Gould and Reyes, 1983; Palmier, 1985; Warwick, 1987; Khan, 1988; Alatas, 1991; Padila, 1995; Cummings, 1995; Yoon, 1996; Banarjee, 1996; Mauro, 1997; Speville, 1997; Quah, 2000). Palmer, for example, stated that in a condition in which a person has few opportunities for corruption, good salary, and effective policing, corruption will be minimal; at the other, in a condition in which bureaucrat has many opportunities, poor salary, and weak policing, it will be considerable (emphasis added). (Palmier, 1985: 271-272).

Meanwhile, another formulated that there are four causal factors of corruption, namely, greed, opportunities, needs, and exposures, as it is formulated by Jack Bologne in his GONE theory (BPKP, 1999: 467). This perspective then classified those four causal factors of corruption into two factors, namely subjective and objective factors. Subjective factors cover needs and greed, whereas objective factors include opportunities and exposures.

Either perspective stating that there are three causal factors of corruption or the one believing that there are four causal factors of corruption, both admit that corruption is related to subjective factor (human) and objective factor (system). Recently, those two causal factors 
of corruption were popularized as propensity or intention factor and opportunity factor. Causal factors coming from inside an individual (human) are called as propensity or intention including needs, greed, and salary, whereas the causes coming from outside an individual (human) are called opportunity including opportunity, exposures, and various negligence of situation and other condition causing people to commit corruption freely) (see: Pope, 2007).

In line with the statement, this research made use of the terms "human factor" and "system factor". Human factor referred to all causal factors of corruption coming from inside an individual (subjective), namely needs, greed, and salary, whereas system factor covered opportunity, exposure, situation and condition made or ignored by government leading to individual to commit corruption bravely.

What is meant by corruption connected to system issue referred to weak system in government that was not able to control administrative process properly so that the window of opportunity is "wide open" for public servants or government to commit corruption. Several cases in some developing countries even make it clear that the weak of the system is made by design by the power elites themselves so that they can commit corruption unimpededly (see Andreski, 1986; Olson, 1993; Moody-Stuart, 1997 on cleptocratic state). Dealing with corruption related to moral issue, the focuses of discussion were quality of government human resources government that could not control itself. Moral and system were two points becoming the focuses of discussion in this research.

Nowadays, moral becomes focus of attention of the activists in their effort to confront corruption. No nation in this world has the right to claim the moral high ground (Pope, 2007). Therefore, moral improvement efforts continue to be urged and recommended to be carried out all the time. Even though it is often stated, in textbook dealing with strategy corruption eradication strategy, that both moral and system factors are equally important to improve, it is not an exaggeration to state that between moral and system it seems that moral is more important to notice about.

If corruption is recognized as the act motivated by the merging of intention and opportunity factors - (see Pope, 2007; Quah, 2000; Corpuz, 1957; Suwanagul, 1962; Day, 1966; Mackie, 1970; Palmier, 1985; Padila, 1995; Cummings, 1995; Yoon, 1996; Banarjee, 1996; Mauro, 1997; Knaspp, 1072; Gould and Reyes, 1983;Warwick, 1987; Speville, 1997; Khan, 1988; Alatas, 1991) - where intention is the reflection of moral (Akbar, 2008), therefore, even though the opportunity for corruption has widely opened, there will be no corruption if the moral value is well established. This belief does not work vice versa. How is it that? It is due to the fact that for those who are immoral, opportunity can be created. The motivators generally believe that strong intention is the most powerful energy to make the intended purpose come true.

In a book entitled Confronting Corruption in its chapter on Lessons Learned, Jeremy Pope explained that corruption occurred in a country is the manifestation of the low moral quality of the nation in that country. There was a time when Western Europeans in particular regard themselves as being highly civilized and morally superior when it came to corruption. But when they realized that many Western Europeans involved in corruption and 'black' money - though they did not do it in their jurisdiction - they no longer dared to declare proudly that Western European was a morally superior nation (Pope: 2007, 536).

Therefore, corruption problem tends to deal with "moral issue" more than "system issue". This indication once also proposed by Susan Rose-Ackerman (1998) in the report of her research on corruption in Italy. Rose-Ackerman indicated that corruption was not a matter of state system or governance system, but it is a matter of government's moral decay. An assumption stating that corruption occurs more frequently in country based on the system of 
authoritarian government than in the country developing the system of democratic government is not always true. The truth is that whatever the government system is (either it is authoritarian or democratic) corruption is more likely to flourish if both officials and society are corrupt (Rose-Ackerman, 2006). Therefore, if corruption occurs in almost all country with various government system variants, none can be stated as euphemism but "the low moral quality".

Talking about moral certainly could not be separated from the source of moral teachings itself, namely religion. Any religion must have been guiding and teaching its devotees to have good moral conduct. Islam is one of the religions providing teachings and guidance to all mankind in order to have high moral quality. Prophet Muhammad (S.A.W. - Peace be upon him), then, sent by God to do his main mission, that is, to perfect akhlaaq (morality) for the whole of mankind so that all mankind has akhlaqul-karimah (high and noble moral conduct). Therefore, it was not by chance that this research observed that corruption is a matter of moral and it is important to seek out basic principles of moral teachings that could be used as reasoning background to improve the moral decay. The researcher chose the basic principles of Islam in this research because he believes that Islam has many principles and basic values relevant to be used as reasoning and development background in composing corruption eradication model.

There were two problems formulated in this research, namely (1) What were the Islamic teachings promoting corruption-free governance?; (2) What was the governance model making use of the basic principles of Islamic teachings (as reasoning background) as preventive efforts to eradicate corruption?

This research aimed to (1) Inventory, identify, analyze, and explain basic principles taught in Islam relevant to governance principles and corruption eradication. (2) Formulate the model of good and anti-corruption governance based on basic principles taught in Islam.

The results of this research ware intended to be alternative solution base for the effort to realize good governance and corruption eradication, especially through religious approach.

\section{Research Methods}

This research belongs to qualitative research, library research to be precisely. There were two literature categories to research, namely (1) Primary literature; and (2) Supporting literature. Primary literature studied was the Quran and the abridged collections of authentic Hadith of Prophet Muhammad (S.A.W), especially the ones dealing with basic values of Islam teachings indicating governance principles and anti-corruption. Studied supporting literatures cover books discussing basic principles or values of Islam teachings on governance and anticorruption referring to verses of Quran or Hadith.

This research did not specifically determine research location for data collection location. For the need of explaining location where the research was conducted and arranged model implication, this research determined that research location was Indonesia. Therefore, the research location was determined only for the sake of determining analysis territory of practical implication on the arranged model. The research was conducted for ten months. It started from September 2007 to September 2008. However, the research process continued running even when the research results started to be written.

The collected primary data were verses of Quran and Hadith indicating basic principles of Islam teachings on governance and anti-corruption. Since the collected data were verses of 
Quran and Hadith, the sources of primary data were the Quran and the abridged collections of authentic Hadith of Prophet Muhammad (S.A.W). Secondary data were firstly collected and inventoried before the primary data were collected. Secondary data were needed to lead the researcher to reach and find primary data. The secondary data in this research covered literatures discussing the perspective of Islamic teachings on governance and anti-corruption. It is from the secondary data that the researcher got the idea and found the verses and Hadith relevant to the collected primary data.

Analysis developed was interpretive analysis or tafsir. In Arabic, the word tafsir is synonymous to bayan, izhar, or idhah meaning clear. According to Muhammad Qosim in his book Dirasat fi Manahijil Qur'an, is science that can better understanding of Quran, explain its meaning, expound its laws, and eliminate the problems in its verses. Whereas according to Muhammad Husain Adz-Dzahaby in his book entitled Tafsir wal Mufasirun, tafsir is science discussing the intentions of Allah S.W.T (in the Quran) based on human ability. This science covers anything explaining meaning comprehension, its explanation, and its implicature.

There are many approaches in tafsir. This study tended to thematic tafsir approach. What had been done was to compile some verses from several surah (chapter) indicating topic on good governance and anti-corruption and the compiled verses were interrelated to come to certain conclusion.

\section{Research Results and Discussion}

Based on the identification of various indications and content of Holy Qur'an and Hadith dealing with good governance and anti-corruption, the collected data showed that there were ten principles formulated from the Holy Qur'an and ten principles formulated from the Hadith. Each principle, then, was reidentified and classified. By conducting such means, the researcher formulated seven principles of Islamic teachings that could be used as reasoning background to realize anti-corruption and good governance. The seven principles were as they were stated below.

The first principle was at-taqwa (this principle includes teachings and indication covering doing good deeds and preventing bad ones). The second principle was justice (this principle includes teachings and indication covering upholding justice, prohibiting monopoly, prohibiting to accept gratification). The third principle was al-amanah (trust). This principle includes teachings and indication covering anti-corruption, prohibition of committing corruption, prohibition of deceiving and neglecting the people. The next principles were recruitment and regeneration (These principle include teachings and indication covering prohibition of requesting position and promoting ambitious officials, suggestion to promote pious officials, developing merit system and avoiding spoils system or nepotism). The fourth principle was deliberation (this principle includes teachings and indication dealing with prohibition of deciding a lawsuit while experiencing state of anger). The fifth principles were responsible and protective (this principle includes teachings and indication a leader should be strong and trustworthy, tolerant, thoughtful. The principle also deals with government's duties to the people, namely to protect, to facilitate, to show tender and compassionate acts). The seventh principle was to build system and strategy emphasizing on the need to build or develop system and strategy that give guaranty of legal and exposure security on all kinds of system violation. 
After comprehending, contemplating, and interpreting contextually, the researcher constructed the seven principles into basic model of anti-corruption and good governance based on Islamic point of view. The underlying thoughts developed by the researcher to construct the model were as follows:

Firstly, the principles of Islamic teachings could be understood structurally by following the most basic concepts to the most operational ones. In this case, the researcher identified attaqwa as the most basic principle underlying other principles. Secondly, in line with the context of this study, the principles of justice, trustworthiness, and responsible are the main principles after at-taqwa. Therefore, the researcher identified those three principles, namely, al-adl (just), al-amanah (trust), and al-mas'ulyah (responsibility) as the main principles. The third, the next three principles dealing with bureaucracy human resources coaching, service, and policy were identified as more operational principles. The fourth, the researcher constructed the model by identifying three pillars of public administration (government), namely bureaucracy, service, and policy. The more operational principles of Islam were related to those three pillars. The fifth, the model was constructed to realize good administration, good governance, and low level of bureaucratic corruption (anti-corruption). The model of anti-corruption and good governance model as the result of the construction of this study can be seen in figure 1 .

The proposed model in this research was arranged based on principles and basic values taught in Islam. The principles and basic values adopted were at-taqwa, al-adl, al-amanah, and al-mas'uliyah. Those four principles are the main background everyone, group, organization, even government must have and practice if the goal is to create a better life order among mankind (in worldly life) and in Allah's eyes (in hereafter life).

At-taqwa principle is basic teaching Allah S.W.T outlines to all mankind since the ages of Prophet Adam (A.S) until the ages of Prophet Muhammad (S.A.W). The command of Allah S.W.T to the mankind to have taqwa of Him is not only for those who have faith on Him but also for those who have no faith yet on Him. The essence of at-taqwa principle is to teach every individual to worship (having faith on) Allah S.W.T, to obey His commandments and to avoid His prohibitions. According to Islam, this principle should become cornerstone of life for every individual wherever he lives, whatever he is, and in whatever condition he is. Based on Islamic pint of view, the measure of goodness is not about facing the West or the East or other direction, but goodness is taqwa. Even based on the view of Allah S.W.T, the most honoured or noble of persons in the sight of Alláh are those who have greater taqwa. At-taqwa principle was very relevant for being treated as the cornerstone for the governance to realize intended society life order. Even, at-taqwa should become the main (basic) cornerstone prior to other principles. The model developed in this researched treated at-taqwa as the most essential basic principle.

The second principle was al-adl. Islam is a fair religion and justice. Islam orders every Muslim (either as an individual or as group of society) to be fair and to uphold justice. This command is mandatory for Muslim to implement. Those who ignore the command and disobey it will be sinful and receive severe punishment form Allah S.W.T in hereafter life. Command to do justice works either for the person himself, close relative, members of society, even to others who have different belief whereas the command to uphold justice is related to the command that every Muslim should actively struggle (jihad) to uphold justice. A Muslim who knows and becomes a witness of injustice action should be brave to defend others who are treated unfair, even if the case is submitted to the trial, he must be eager to be a witness for the sake of upholding justice in society. This teaching was very relevant for being treated as basic principle of the practice of national and state life. The principle of al-adl did not only 
become an affair in a domain of individuals, groups or religions but it covers all domains of life. Nevertheless, this principle is of second important compared to the principle of at-taqwa. It is based on what is written in the Quran (act equitably, that is nearer to piety).

The third principle was al-amanah (trust). Islam teaches that every person who has received entrusted things, authority, or power should be amanah (trusted and trustworthy). The free translation of amanah is honesty, trustworthy, accountability, or trust. In Islam teaching, an individual has an obligation to do amanah to other having the right to receive it. Related to the context of this study, governance matter was amanah (entrusted thing) which should be carried out well, honestly and fairly for the sake of the people. One of important implications of the teachings on amanah in the domain of governance was the absolute prohibition of committing corruption and fraud what so ever. The command for conducting amanah would be easily carried out by those who have taqwa. Therefore, the principle of alamanah in this model is positioned (constructed) equal to the principle of al-adl which is above the principle of at-taqwa.

The fourth basic principle was al-mas'uliyah (responsibility). Islam states firmly that every individual is a leader and every leader will be asked for accountability about what he has done to those under his guardianship. Seen from the context of this study, this principle was closely relevant if it was related to the Hadith teaching that every ruler (government) will be asked about any shortcoming in ruling those Allah has put under their guardianship. The given accountability refers to the accountability to the people about what he has done to them and the accountability to Allah S.W.T about the people he has ruled. In this research, almas'uliyah principle was equalized to al-adl and al-amanah principles. In this model, those three principles were constructed as main principles underlaid by basic principle, that is attaqwa.

Besides appreciating those four principles (one basic principle and three main principles), the researcher also developed three operational principles in accordance to the research topic. Each of the three intended principles related to bureaucracy, service, and policy, which are the three main pillars of the existence of governance. These last three principles were called operational principles. It is called operational principles because these principles were directly related to the function and operation of governance. These operational principles were underlaid by basic principle (at-taqwa) and main principles (al-adl, alamanah, and al-mas'uliyah).

Dealing with bureaucracy, Islam taught and indicated that ambitious, hypocrite, and unprofessional official should not be promoted. On the contrary, Islam commanded to promote pious, good at his job (professional), people-oriented official. The researcher had not found the specific term taught in Islam yet to name this principle. For the sake of this study, the principle taught in Islam dealing with bureaucracy named "pious bureaucracy".

In line with service, Islam taught and indicated that service given to the people (public service) should be carried out earnestly, sincerely, and based on religious-service orientation (non-popularity oriented). The researcher, again, had not found specific term to name this principle. But the researcher had found a term which approximately was in accordance to name the principle, that is, "Prohibition of Sum'ah". Sum'ah is to conduct good deed for the sake of popularity instead of for the pleasure of Allah S.W.T.

Dealing with policy, Islam taught and indicated that it was human obligation to create legal system and clear and binding rules working equally without discrimination for all levels and groups in society. The system should be arranged based on deliberation resulting in binding agreement (civil contract) and it should be obeyed by all sides. Violation of the system had to be detained assertively, fairly, equally, and a warning for all people. 
It was apparent that the model was arranged based on seven Islamic principles categorized into three groups. The first group consisted of one basic principle, namely Attaqwa. The second group contained three main principles, namely al-adl, al-Amanah, and almas'uliyah. The third group covered three other principles that were more operational in their practice. They were principles dealing with governance's function and operation covering bureaucracy, service, and policy.

\section{Conclusion and Suggestions}

This research formulated several conclusions. Firstly, there were ten principles indicating anti-corruption attitude taught in Islam through Quran. Those principles are taqwa, amanah, adl (upholding justice), responsibility, solving problem through deliberation (democratic, logical, accessible, and transparent). Leader should be strong and temptation-resistant; the duties of a leader to his people were to protect and to serve, to demand not to be served; tolerant and lenient; a leader's missions were to implement amar ma'ruf (commanding or spreading what is just) and nahi 'anil munkar (forbidding or preventing what is evil), to create strong constitutional system to cope with potential crime attack (either from the inside or from the outside) that can destroy or lapidate life order, and to ensure legal certainty.

Secondly, there were ten principles indicating anti-corruption attitude taught in Islam through Hadith. Government should consist of pious officials (having high level of taqwa, amanah, justice, responsibility); governance should be run trustily, justly, responsibly; Government's duties were to protect the people, to facilitate people's affairs, to implement amar ma'ruf and nahi 'anil munkar, to decide case deliberatively, justly, logically, unemotionally; attitudes that should be developed in running government were to have compassion to the people, to have empathy for the people, to be tolerant and lenient to the people, to facilitate the people, to undeceive people, to reject gratification; Attitudes that should be avoided were to commit corruption, monopoly, embezzlement, collusion, nepotism, to ignore the people, to receive gratification (gift giving). Dealing with recruitment and development, government should promote pious official instead of promoting weak and ambitious (demanding for position) official. Government's rights were being obeyed (supported) so long as the government does not call to a sin; in order to remove the opportunities for corruption, the Prophet Muhammad S.A.W taught that salary, incentive, and facilities needed by government should be fulfilled proportionally; Corruptor should be severely punished. His case and punishment should be exposed publicly as a lesson so that similar deed will not happen again.

The third, model of anti-corruption governance based on Islamic view was government should be run based on the principles of at-taqwa (God-Consciousness), al-amanah (trust), al$a d l$ (just).

This research also formulated a number of suggestions (recommendations). The first, after the inception of the shift in the third phase of public administration perspective, namely New Public Service, the discipline of public administration science was truly challenged to be able to make use of contribution from other disciplines as well as the principles and fundamental values from other sources, in order that the discipline of public administration science could adjust itself to the demands and environmental changes. As a consequence of what happened, the scientists and academicians of public administration needed to continue making creations to produce new model or theory which was derived from the previous theory 
or model. Therefore, it is recommended that the theoretical development of public administration science was integrated in such a way to attract the interest and attention of the people to learn about and develop it, especially in constructing a model of good and anticorruption governance.

Secondly, in addition to be accessible and to remain open-minded embrace development of the discipline of other sciences, scientists and academicians of public administration needed to explore fundamental principles and values developing among society that was considered to have an opportunity to be enforced universally. The exploration of the fundamental principles and values was apparently needed to be done in such a way so that the results could be useful for the academicians to construct or create new models for the development of public administration theories, especially to construct anti-corruption governance model.

The third suggestion was the fact that the model developed in this research needed to be re-examined and improved continually. Therefore it was recommended to anyone who intends to and is interested in developing this model to do it more seriously. The goal is nothing but to perfect the model and to enrich the corpus of the concept and model of Governance.

The fourth, based on the research results of various literatures, corruption tended to be a matter of moral more than other matters. Therefore, in order to create anti-corruption governance, any effort to implement models specifically constructed for the intended need was important to be carried out. The recommended approach was administrative approach whose main interest was to treat human factor (human resources) and the priority of human resource development were placed on the improvement of the moral quality (faith and Godconsciousness).

The fifth, it was the fact that effective application of the law was indeed very advisable to raise the spirit of bureaucracy so that it could work well and not corrupt. But far more important than that was the quality of faith and God-consciousness. Therefore, dealing with the application of the law in order to be more effective, it would be better to base norms and sanctions applied on religious norms and teachings. The study recommended a number of basic principles and values of Islam to be the cornerstone of thought.

The sixth, there were five main points recommended in this research in order to be able to realize anti-corruption governance. Those five points were (1) The needs for reformation and improvement of bureaucracy character; (2) Building an ethos that working (to serve or to be on duty) was the devotion and worship whose domain did not only deal with worldly affairs but also the affairs of the hereafter; (3) Every official should have high commitment to the "amanah", which was trusted, trustable, and doing no treachery; (4) Public officials (bureaucracy) should develop themselves into the authoritative figure; (5) Public officials must have the personality exuding sense and attitude of affection to the people they serve; (6) Conducive, facilitative, becoming problem solver, instead of actually creating a problem; (7) It is necessary to do reformation in governance process systemically.

Some principles and basic values needed to be developed were the principles of justice, state defense, deliberation, democracy, tolerance, anti-corruption, collusion, nepotism, monopoly and other manipulative conducts. 